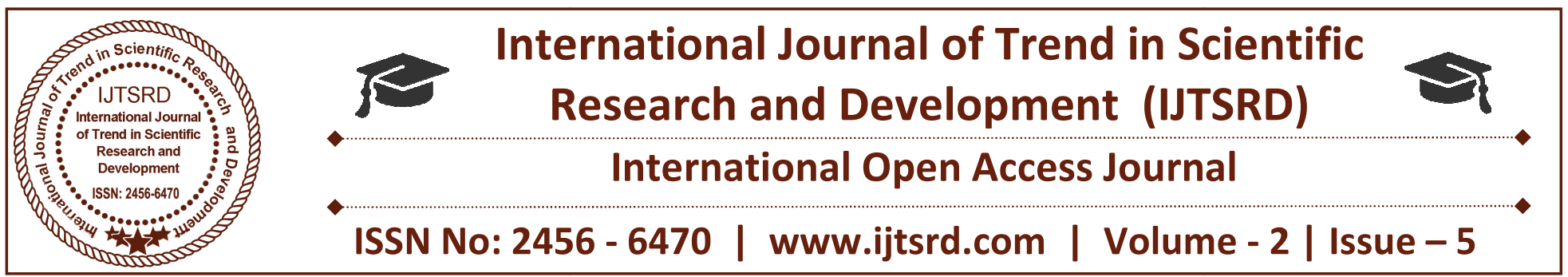

\title{
Isolation, Identification of Probiotic Bacteria Present in Milk
}

\author{
Shobha Mehra ${ }^{1}$, Vimla Mehra $^{2}$, Dinesh Bhauryal ${ }^{3}$ \\ ${ }^{1}$ Ph.D. Student, ${ }^{2}$ M.Sc. Student, ${ }^{3}$ M.Tech. Student \\ ${ }^{1}$ Department of Biotechnology and Microbiology, ${ }^{2}$ Centre for Research Studies (CRS), \\ Noida International University, Gautam Budh Nagar, Noida, Uttar Pradesh, India \\ ${ }^{2}$ Department of Microbiology, Swami Rama Himalayan University, \\ Doiwala, Dehradun, Uttarakhand, India
}

\section{ABSTRACT}

The aim of this study was to present some data on isolation, growth, and antimicrobial activity, effect of $\mathrm{pH}$, heat, and sensitivity to proteolytic enzymes of lactobacillus as probiotic bacteria. A large amount of probiotic bacteria is present in milk or milk products which are mainly lactic acid bacteria (LAB). Lactic acid bacteria (LAB) including Lactobacillus spp. Isolation, identification of lactic acid bacterial (LAB) was done by Gram's staining and catalase test and further confirmation was based on morphological, cultural, physiological and different biochemical tests. A total four isolates viz. Lactobacillus fermentum, L. casei, L. acidophilus and bifid bacterium longum was identified after different biochemical analysist which were also showed reliable probiotic properties. The antibacterial activity of lactic acid bacteria (LAB) isolated from raw milk against common enteric pathogens. The antagonistic properties of these isolates against Escherichia coli, Staphylococcus aureus, were examined using agar well diffusion method.

Keywords: Isolation; Probiotics; Milk; Lactobacillus species; Antimicrobial activities

\section{INTRODUCTION}

Probiotics are living, health-promoting microorganisms that are incorporated into various kinds of foods. The ability of probiotics to withstand the normal acidic conditions of the gastric juices and the bactericidal activity of the bile salts, as well as the production of lactic acid that inhibits the growth of other microorganisms, allow them to be established in the intestinal tract (Catanzaro J, 1997). The history of probiotics began with the history of man by consuming fermented foods that is well known. (Gismondo, et al., 1999, Guarner et al., 2005) In 1908 a Russian researcher Ellie Metchnikoff, who won a Nobel Prize, firstly proposed the beneficial effects of probiotic microorganisms on human health. Metchnikoff hypothesized that Bulgarians are healthy and long lived people because of the consumption of fermented milk products which consists of rod shaped bacteria (Lactobacillus spp.). Therefore, these bacteria affect the gut microflora positively and decrease the microbial toxic activity. (Gismondo, et al., 1999,Çakır 2003, Chuayana, et al., 2003). Microbial cultures have been used for thousands of years in food and alcoholic fermentations, and in the past century have undergone scientific scrutiny for their ability to prevent and cure a variety of diseases. Elie Metchnikoff in 1907 first introduced the probiotics concept in 1908, when he observed the long life of Bulgarian peasants who consumed fermented milk foods. He suggested that lactobacilli might counteract the putrefactive effects of gastrointestinal metabolism. The concept of probiotics has evolved from the work of Metchnikoff (1908) although the term was probably first used by Lilly \&Stillwell (1965).

\section{MATERIALS AND METHOD: Sample collection}

Milk samples collected from local cow and buffalo were used for isolating probiotic microorganisms. The unpasteurized milk samples were added separately to MRS broth and incubated at $30^{\circ} \mathrm{C}$ for one week under static conditions for enrichment of microorganisms. 


\section{Isolation of lactic acid bacteria from Milk}

Probiotic microorganisms were isolated by using MRS (peptone, meat extract, yeast extract, glucose, and tween (80) or MRS HIMedia. The collected samples were suspended and $0.5 \mathrm{ml}$ of sample was serially diluted up to $10^{-7}$ concentration. About $100 \mu \mathrm{L}$ of each dilution were spread on MRS agar plates and then incubated at $37^{\circ} \mathrm{Cfor} 24$ hours. The isolated colonies were sub-cultured and stored at $4^{\circ} \mathrm{C}$ until further use.

\section{Identification of Lactic acid bacteria:}

Identification of the selected isolates with the desired antimicrobial activity was carried out using microscopic and biochemical methods as described by Michael et al., biochemical characteristics observed included Lactic acid production test, different sugar fermentation (lactose and glucose), catalase tests, $\mathrm{pH}$ test (growth at 6,7,10), Temperature test (growth at $10^{\circ} \mathrm{C}, 40^{\circ} \mathrm{C}$ and $60^{\circ} \mathrm{C}$ ). Pure culture isolated on MRS agar slant was identified with the help of biochemical tests like catalase test and sugar fermentation test etc.

\section{Microscopic identification by Gram's staining:}

The colonies isolated were stained by Gram's staining method, in order to identify the morphology and gram reaction of the bacteria. A thin smear was prepared on a clean slide using the isolated individual colony. The smear was heat fixed and cooled. The dried smear was then flooded with the primary stain-crystal violet solution and allowed to stand for 1 minute. Then it was washed with water and flooded with gram's iodine solution and allowed to stand for 1 minute. The slide was then washed with decolouriser. Then the slide was flooded with a counter stain - safranine for 1 minute. After drying, the stained smear was observed under oil immersion lens 100x.

\section{$\mathrm{NaCl}$ tolerance}

MRS Broth with $1 \%, 2 \%, 3 \%, 4 \% \mathrm{NaCl}$ (w/v) were inoculated with a 0.1 mlactivated culture of bacteria isolated from stool and vaginal samples and incubated at $37^{\circ} \mathrm{C}$ for $48 \mathrm{hrs}$. Growth of the organism measured calorimetrically at $540 \mathrm{~nm}$.

\section{Effect of $\mathbf{p H}$ on growth rate:}

MRS Broth with $\mathrm{pH} 3,4,5,6,7,8$ were inoculated with a $0.1 \mathrm{ml}$ activated culture of bacteria incubated at $37^{\circ} \mathrm{C}$ for $48 \mathrm{hrs}$. Growth of the organism measured calorimetrically at540 $\mathrm{nm}$.
Effect of temperature on growth rate:

The effect of growth as well as bacteriocin production was evaluated by incubating the cultures for 24 hours at various temperatures $\left[10^{\circ} \mathrm{C}, 40^{\circ} \mathrm{C}\right.$ and $\left.60^{\circ} \mathrm{C}\right]$.

\section{Catalase tests:}

In the center of the cavity slide the given bacterial culture was smeared. A drop of $3 \% \mathrm{H}_{2} \mathrm{O}_{2}$ was added on the smear and observed or the elevation of free oxygen as bubbles which indicates positive test, whereas the negative reaction fails to form the oxygen bubbles.

\section{Determination of Sugar Fermentation}

Two different sugars; Glucose and Lactose were used for sugar fermentation assay. At first every sugar was dissolved in deionized water at a final concentration of $5 \%(\mathrm{w} / \mathrm{v})$, then sterilization of sugar solutions were done by filter paper with $0.22 \mu \mathrm{m}$ pore diameter. MRS broth ( $\mathrm{pH}$ 6.5) was taken into screw cap test tube and phenol red $(0.01 \mathrm{~g} / \mathrm{L})$ was added into the tube as a $\mathrm{pH}$ indicator. Inverted Durham's tubes were placed and the medium was autoclaved at $121^{\circ} \mathrm{C}$ for $15 \mathrm{~min} .1 \mathrm{ml}$ different sugar solutions were inoculated into different tubes and $200 \mu \mathrm{l}$ overnight liquid cultures were inoculated into the broth medium. Incubation was performed anaerobically at $37^{\circ} \mathrm{C}$ for $24 \mathrm{~h}$. Sugar fermentation was observed, as the acid production change the color of medium from its original to yellow and formation of gas in test tubes.

\section{Inoculum preparation:}

The strains of lactic acid bacteria were propagated in MRS broth at $37^{\circ} \mathrm{C}$ for 24 hours and bacterial biomass was collected by centrifugation at 6000rpm for 10 min, subsequently cell pellet was washed with sterile saline solution [0.85\% Nacl] and was suspended in the same solution to a final optical density at $540 \mathrm{~nm}$. This cell suspension was used as the inoculum for determining the growth pattern and antimicrobial activity.

\section{Detection of antimicrobial activity:}

The agar diffusion bioassay described by Herreros et al., (2005) was used to screen for bacteriocin producing LAB. The liquid cultivation of the purified LAB culture was studied in MRS broth by aseptically inoculating a loop full of cells and incubated at $37^{\circ} \mathrm{C}$ for 24 hours under anaerobic condition. The culture broth was centrifuged at $10000 \mathrm{rpm}$ for $10 \mathrm{~min}$ at 
$40^{\circ} \mathrm{C}$ and the inhibitory activity were determined by using the supernatant (bacteriocin like substance) of the broth after adjusting its $\mathrm{pH}$ to 7.0 by means of $1 \mathrm{M}$ sodium hydroxide to exclude antimicrobial effect of organic acids. The method adapted for the evaluation of antagonistic property was agar well diffusion assay (WDA).

Antimicrobial activity against indicator organisms: For detection well diffusion method was used. For the agar well diffusion assay, an overnight culture of the indicator strain was used to inoculate agar growth media at $37^{\circ} \mathrm{C}$. Wells of $5 \mathrm{~mm}$ diameter were cut into $\mathrm{N}$ - agar plates and $10 \mu \mathrm{l}$ of culture supernatant fluid containing antibacterial activity was added and incubated at $37^{\circ} \mathrm{C}$ for $24 \mathrm{hrs}$ and zones were observed.

Staphylococcus aureus and Escherichia coli were indicator strains used against Lactobacillus.

\section{III.RESULTS AND DISCUSSION}

\section{Isolation and characterization}

Different Lactobacilli were isolated from the collected milk samples $L$. acidophilus, $L$. salivarius and $L$. delbrueckii subsp. bulgaricus isolates were specifically detected from cow milk samples. Whereas, $L . \quad$ acidophilus, $\quad L . \quad$ fermentum and $L$. pentosus isolates were detected from buffalo milk samples.

These isolates were given the symbol $\mathrm{C}\left(\mathrm{c}_{1}, \mathrm{c}_{2}\right.$, $c_{3} \ldots .$. and $c 6$ ) for bacterial isolates from cow milk, the symbol $B\left(b_{1}, b_{2}, b_{3} \ldots\right.$...and $\left.b_{6}\right)$ for bacterial isolates from buffalo milk. Description of culture morphological and microscopical characteristics was also included in Table 1.

Table1: Morphological and microscopical characteristics of LAB isolates from cow milk and buffalo milk.

\begin{tabular}{|c|c|c|c|}
\hline Isolate sample & Colony shape & Colony size & Colony color \\
\hline C1 & Round, smooth,flat & 2.0 & White \\
\hline C2 & Round, smooth,flat & 1.0 & White \\
\hline C3 & Round, convex,flat & 3.0 & Yellowish white \\
\hline C4 & Round, smooth,raised & 1.4 & White \\
\hline C5 & Round, smooth,flat & 3.1 & White \\
\hline C6 & Round, smooth,flat & 2.0 & White \\
\hline B1 & Round, convex,flat & 1.3 & White brillant \\
\hline B2 & Round, raised,flat & 2.0 & White \\
\hline B3 & Round, smooth,flat & 2.0 & White brillant \\
\hline B4 & Round, smooth,flat & 3.0 & White \\
\hline B5 & Round, convex,flat & 1.0 & White \\
\hline B6 & Round, smooth,flat & 1.5 & White \\
\hline
\end{tabular}

\section{Biochemical tests of isolated LAB}

After confer the Lactobacillus Colonies on a MRS Himedia, we performed several biochemical tests, for the further confirmation of Lactobacillus and identification of Lactobacillus Strain. These all biochemical test shown that our isolated microorganism from Milk is may be lactobacillus shirota and lactobacillus casei. By performing Gram Staining we observed purple color gram positive rod shaped Lactobacillus species.

Table 2: Biochemical tests of isolated LAB

\begin{tabular}{|c|c|c|c|c|}
\hline Isolate sample & Gram strain & Catalase test & Glucose & Lactose \\
\hline C1 & $+v e$ & $-v e$ & $+v e$ & $+v e$ \\
\hline C2 & $+v e$ & $-v e$ & $+v e$ & $-v e$ \\
\hline C3 & $+v e$ & $-v e$ & $+v e$ & $+v e$ \\
\hline C4 & $-v e$ & $-v e$ & $-v e$ & $+v e$ \\
\hline C5 & $+v e$ & $+v e$ & $+v e$ & $-v e$ \\
\hline C6 & $+v e$ & $-v e$ & $-v e$ & $+v e$ \\
\hline B1 & $+v e$ & $-v e$ & $+v e$ & $+v e$ \\
\hline B2 & $-v e$ & $+v e$ & $+v e$ & $+v e$ \\
\hline B3 & $+v e$ & $-v e$ & $-v e$ & $+v e$ \\
\hline
\end{tabular}


International Journal of Trend in Scientific Research and Development (IJTSRD) ISSN: 2456-6470

\begin{tabular}{|c|c|c|c|c|}
\hline B4 & +ve & -ve & +ve & -ve \\
\hline B5 & +ve & +ve & +ve & +ve \\
\hline B6 & +ve & -ve & +ve & +ve \\
\hline
\end{tabular}

Role of temperature and pH on the growth of the organism

It has been found that the growth of bacterial organism present in milk was found to be the maximum at the $\mathrm{pH}$ of 7.0. The optimum temperature for the maximum growth was found to be $40^{\circ} \mathrm{C}$.

Table 3:

\begin{tabular}{|c|c|c|c|c|c|}
\hline Isolate sample & Ph at $4 h r$ & Ph at 6hr & Temp $10^{\circ} \mathrm{c}$ & Temp $40^{\circ} \mathrm{c}$ & Temp $60^{\circ} \mathrm{c}$ \\
\hline $\mathrm{C} 1$ & $0.2 \pm 0.01$ & $0.4 \pm 0.01$ & - & +++ & + \\
\hline $\mathrm{C} 2$ & $0.2 \pm 0.00$ & $0.3 \pm 0.04$ & - & ++ & + \\
\hline C3 & $0.3 \pm 0.01$ & $0.4 \pm 0.07$ & - & ++ & + \\
\hline $\mathrm{C} 4$ & $0.4 \pm 0.01$ & $0.5 \pm 0.02$ & - & +++ & ++ \\
\hline $\mathrm{C} 5$ & $0.3 \pm 0.01$ & $0.4 \pm 0.03$ & - & +++ & + \\
\hline C6 & $0.5 \pm 0.00$ & $-1.1 \pm 0.01$ & - & +++ & + \\
\hline B1 & $0.6 \pm 0.01$ & $1.2 \pm 0.01$ & Q nata & +++ & + \\
\hline $\mathrm{B} 2$ & $0.4 \pm 0.02$ & $0.6 \pm 0.03$ & $-8 /(2)$ & ++ & ++ \\
\hline B3 & $0.5 \pm 0.07$ & $0.8 \pm 0.01$ & - & +++ & + \\
\hline B4 & $0.3 \pm 0.01$ & $0.6 \pm 0.01$ & - & + & + \\
\hline B5 & $0.2 \pm 0.01$ & $0.5 \pm 0.06$ & \begin{tabular}{|l|} 
\\
\end{tabular} & +++ & + \\
\hline B6 & $0.4 \pm 0.03$ & $0.9 \pm 0.01$ & $1 \times-$ & ++ & + \\
\hline
\end{tabular}

\section{Antimicrobial activity of against test pathogens}

Bacteriocin like substance was shown inhibitory effect against the growth of Escherichia coli

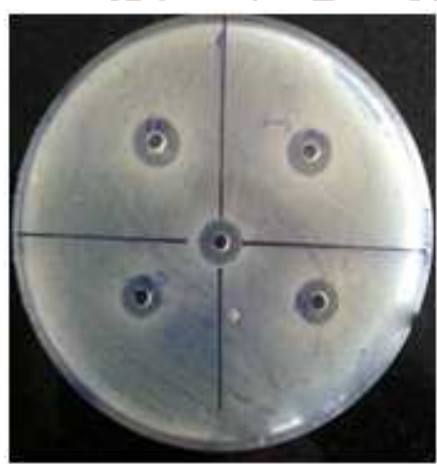

Fig 1: Antimicrobial activity of Bacteriocin like substance(different concentration) on Growth of E.coli.

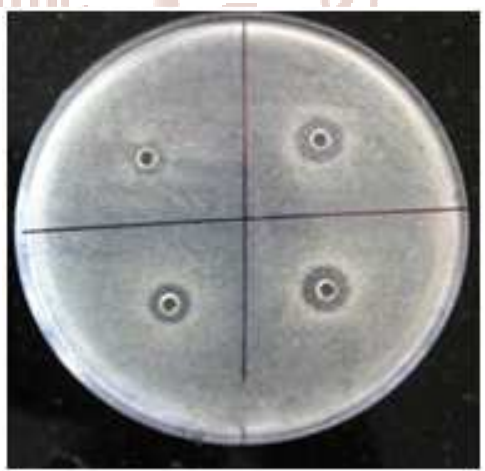

Fig 1: Antimicrobial activity of Bacteriocin Like substance (different concentration) on Growth of Staphylococcus aureus.

Table 4: Screening of the recovered bacterial isolates for antimicrobial activity against test pathogens.

\begin{tabular}{|c|c|c|}
\hline \multicolumn{3}{|c|}{ Zone of inhibition in diameter(mm) \pm SD } \\
\hline Isolate sample & E.coli & S.aureus \\
\hline C1 & $13 \pm 0.4$ & $10 \pm 0.1$ \\
\hline C2 & $11 \pm 0.0$ & $11 \pm 0.4$ \\
\hline C3 & $14 \pm 0.2$ & $10 \pm 0.2$ \\
\hline C4 & $10 \pm 0.1$ & $0.0 \pm 0.0$ \\
\hline C5 & $15 \pm 0.2$ & $13 \pm 0.3$ \\
\hline C6 & $0.0 \pm 0.0$ & $10 \pm 0.0$ \\
\hline B1 & $14 \pm 0.1$ & $12 \pm 0.0$ \\
\hline B2 & $10 \pm 0.2$ & $9 \pm 0.2$ \\
\hline B3 & $0.0 \pm 0.0$ & $0.0 \pm 0.0$ \\
\hline
\end{tabular}




\begin{tabular}{|c|c|c|}
\hline B4 & $13 \pm 0.1$ & $11 \pm 0.0$ \\
\hline B5 & $0.0 \pm 0.0$ & $10 \pm 0.0$ \\
\hline B6 & $12 \pm 0.3$ & $11 \pm 0.1$ \\
\hline
\end{tabular}

\section{DISCUSSION}

This study deals with the isolation, characterization and optimization of bacteriocin produced by Lactococcus lactis from milk. Appropriate dilutions of each sample were placed on MRS agar plates. Creamy white clones showing good colonial development was transferred to fresh MRS plates. The bacteriocins activities were examined and compared among other strains isolated. Finally, the strain showing relatively higher bacteriocins activity was selected. Lactobacillus bulgaricus had antibacterial activity against indicator strains $S$. aureus and $E$. coli which were further characterized. Their antimicrobial substances inactivated by trypsin and designed as bacteriocin. Lactobacillus bulgaricus showed the broadest range of inhibitory action. Since antibacterial activity decreased after treatment with trypsin, but not affected with lysozyme and $\alpha$-amylase, so, the bacteriocins have probably a pertinacious nature. This was in accordance with Gonzalez et al, 1994. Also, the protein nature of bacteriocin was confirmed by its sensitivity to trypsin (Olukoya et al, 1993). Bacteriocin of Lactobacillus bulgaricus on the basis of its stability in the medium, its broad spectrum of activity on some pathogenic and spoilage food bacteria and its high potency of bacteriocin production is recommended as food preservative. In this study, production of bacteriocin was best in MRS broth, or in a medium containing peptone, yeast extract, beef extract, glucose, sodium acetate and Tween 80 .

The inhibitory effect demonstrated by isolate against the indicator bacteria is an indication of possession of antibacterial activity. Results also revealed the presence of the bacteriocin in the test isolate. The production of bacteriocin the bacteria indicates its application as probiotic and as bio-preservative. Morphological and cultural studies revealed that the isolate were gram positive and gram negative and rod shaped bacteria. It was also confirmed as catalasepositive, aerobic, moderate thermophiles. The production medium should be optimized for the better production of bacteriocin. The parameters such as incubation time, $\mathrm{pH}$, temperature, carbon and nitrogen sources were considered to be optimized primarily as reported by many researchers (Trinettaet al., 2008; Wiese et al., 2010). Lactococcus lactis was tested for its growth under various parameters like temperature, $\mathrm{pH}$, carbon and nitrogen sources. $\mathrm{pH}$ and temperature played an important role in cell growth and bacteriocins production. The optimum concentration of these nutrients for maximum growth as well as bacteriocin production was found to be perfect at $\mathrm{pH}$ 7 and 1\% for glucose and bacteriological pepton erespectively. All the LAB isolates survived an incubation period of $4 \mathrm{~h}$ at $\mathrm{pH} 4.0$, but exhibited variation in tolerance to acidic $\mathrm{pH}$. The isolates that exhibited $>80 \%$ growth when compared to controls were grouped as highly resistant (R), $70-80 \%$ as moderately resistant (MR), 40- 60 are sensitive(S) and $<40 \%$ as highly sensitive (HS). Zone of inhibition was observed against $E$. coli species. And isolate of Staphylococcus aureus. Antibacterial activity of the milk isolates against each test organisms was studied. E.coli by isolates for that table 3 shows each isolates were capable to inhibit E.coli. Milk isolates, C1, C4, B5 and B6 are more capable to inhibit E.coli as compare to others. S.aureus Inhibition by B1 \&c4 isolates shows Maximum inhibitory zone. Isolate c3 also shows significant inhibition against S.aureus. Isolates have ability to inhibit S.aureus to treat enter toxin diseses.

\section{CONCLUSION}

Lactic acid bacteria were successfully isolated from milk. Probiotic activities of both the isolates were determined. From the above discussion it could be suggested that, lactic acid bacteria represent a commercial potential source of much-needed new natural antimicrobial agents, which could be promising for management of the present test pathogens.

\section{VI.ACKNOWLEDGEMENTS}

The author extends its acknowledgement to (ChemGeneics Research foundation, Noida) for providing lab facilities to do the research work.

\section{REFERENCES}

1. Aslim, P. Yuksekdag, Z. N.; Sarikaya, E. and Beyatli, Y Determination of the bacteriocin-like substances produced by some lactic acid bacteria isolated from Turkish dairy products. LWT FoodSci. Technol. 2005, 38: 691-694. 
2. Barefoots, S. F. and T. K. Klaenhammer. Detection and activity of lactacin B a bacteriocin produced by Lactobacillus acidophilus. Applied Environ. Microbiol, 1983, 45: 1808-1815.

3. Bengmark, S. Ecological control of the gastrointestinal tract. The role of probiotic flora. Gut, 1998, 42: 2-7.

4. Broadbent, J. R.; Chou, C.; Guillies, K. and Kondo, J. K. Nisin inhibits several gram-positive, mastitis-causing pathogens. J. Dairy Sci., 1989, 72: 3342- 3345 .

5. Carr, F. J.; Hill, D. and Maida, N. The lactic acid bacteria: A literature survey. Crit. Rev. Microbiol., 2002, 28: 281-370.

6. Chin, H. S., Chin, J. S., Kim, J. M., Yang, R. and Yoon, S. S. Detection and antibacterial activity of a bacteriocin produced by Lactobacillus plantarum. FoodSci. Biotechnol. 2001.,10: 335341.

7. Daeschel, M. A. Antimicrobial substances from lactic acid bacteria for use as food preservatives. Food Technol., 1989, 43: 164-166.

8. De Vuyst L. Nisin production variability between natural Lactococcus lactis subsp. lactis strains. Biotechnol. Lett. 1994, 16: 287-292.

9. De Martinis, E. C. P. ; Públio, M. R. P.; Santarosa, P. R. and Freitas, F. Z. Antilisterial activity of lactic acid bacteria isolated from vacuumpackaged Brazilian meat and meat products. Braz. J. Microbiol., 2001, 32: 32-37.

10. Fuller, R. Probiotics in man and animals. J. Appl. Bacteriol., 1989, 66: 365-378.

11. Fisher, J. F.; Meroueh, S. O. and Mobashery, S. Bacterial resistance to beta-lactam antibiotics: compelling opportunism, compelling opportunity. Chem. Rev., 2005, 105: 395-424.

12. Guinane, C. M.; Cotter, P. D.; Hill, C. and Ross, R. P. Microbial solutions to microbial problems; lactococcal bacteriocins for the control of undesirable biota in food. J. Appl. Microbiol., 2005, 8: 1316-1323.
13. Garrity, G. M. Bergey's manual of systematic bacteriology, the proteobacteria, Williams and Wilkins, New York. 1984, vol. 2.

14. Hernández, D.; Cardell, E. and Zárate, V. Antimicrobial activity of lactic acid bacteria isolated from Tenerife cheese: initial characterization of plantaricin TF711, a bacteriocin-like substance produced by Lactobacillus plantarum TF711. J. Appl. Microbiol., 2005, 99: 77-84.

15. Kopp-Hoolihan, L. Prophylactic and therapeutic use of probiotics: A review. J Am Diet Assoc 2001. 101(2): 229-241.

16. Kumar, A. and Schweiser, H. P. Bacterial resistance to antibiotics: active efflux and reduced uptake. Adv. Drug Deliv. Rev., 2005, 57: 14861513.

17. Moreno, I.; Lerayer, A S. L.; Baldini, V. L. S. and Leitão, M. F. de F. Characterization of bacteriocins produced by Lactococcus lactis strains. Braz. J. Microbiol., 2000, 31: 184-192.

18. Parada, J. L.; Sambucetti, M. E.; Zuleta, A. and Rio, M. E. Lactic acid fermented products as vehicles fllforprobiotics.In-New Horizons in Biotechnology. Kluwer Academc Publishers, Boston, Londres, 2003, pp. 335-351.

19. Rodríguez, E.; Arqués, J. L.; Rodríguez, R.; Nuñez, M. and Medina, M. Reuterin production by lactobacilli isolated from pig faeces and evaluation of probiotic traits. Lett. Appl. Microbiol., 2003, 37: 259-263.

20. Vaughan, E. E.; Daly, C. and Fitzgerald, G. F. Identification and characterization of helveticin $\mathrm{V}$ 1829, a bacteriocin produced by Lactobacillushelveticus1829. J. Appl. Bacteriol., 1992, 73: 299-308.

21. Yoneyama, H. and Katsumata, R. Antibiotic Resistance in Bacteria and Its Future for Novel Antibiotic Development. Biosci. Biotechnol. Biochem, 2006, 70: 1060-1075. 